\title{
Assessing the Impact of Good Governance, Church Management and Structure on the Growth and Development of the Church
}

\author{
Ransford Kwabena Awuku- Gyampoh ${ }^{1,3}$ \& Andy Ohemeng Asare ${ }^{2}$ \\ ${ }^{1}$ School of Management, Swiss Management Centre University, Switzerland \\ ${ }^{2}$ School of Management and Economics, University of Electronic Science and Technology of China, Chengdu, \\ China \\ ${ }^{3}$ Faculty of Management and Business, Central University of Nicaragua, Nicaragua \\ Correspondence: Ransford Kwabena Awuku-Gyampoh, School of Management, Swiss Management Centre \\ University. Bahnhofstrasse 20,6300 Zug, Switzerland. E-mail: rkawukugyampoh443@gmail.com
}

Received: January 28, 2019

Accepted: February 18, 2019

Online Published: March 8, 2019

doi:10.5539/ijbm.v14n4p99

URL: https://doi.org/10.5539/ijbm.v14n4p99

\begin{abstract}
Management is a business function that provides leadership support to organizations' resources to realize strategic goals and objectives. While churches are not precisely business organizations tied with specific management practice as requirements including other complex legal requirements such as filing returns and payment of taxes, they engage in activities that require adequate planning and execution if they are to be successful and impact to the church's growth and development. Hence, there is a need for an effective governance system for churches that will ensure efficient and effective utilization of resources and management practices in the growth and development of Churches. This paper, therefore, aims at presenting an analysis of good governance, effective managerial strategies and church structure for church growth and development. This study will employ the use of content analysis of literature as the main components in the study in the areas of effective managerial practices, corporate governance and organizational structure and its impact on Church growth and development. The study will systematically answer various questions under the study which eventually contributes towards the establishment of good governance, effective management and Church Structure on the growth and development of Churches. The study will, therefore, unearth the relationship between good governance, church management and structure on the growth and development of churches. It will further recommend leaders of churches the elements of good governance, management and the structure of their church that have to be taken into consideration in their decision making.
\end{abstract}

Keywords: churches, good governance, management techniques, church structure

\section{Introduction}

\subsection{Governance Systems and the Church}

Within organizations and organizational structures, corporate governance, management practices and organizational structure plays a significant role especially when it comes to the management of the organization's welfare, ranging from management of the organization's resources to its daily transaction and interactions with other organizations and its target audience. Corporate Governance is a crucial component not only to the daily running's and operations of the organization but also for its ultimate growth and development. According to the principles of corporate governance for charities by the Institute of chartered secretaries and administrators international as cited by Worldbank.Org (2018), governance concerns the availability and utilization of structures, functions, processes and organization's traditions are in place within the context of a program authorizing environment. Thus, to ensure that the program is attaining its aims in an effective and transparent mode.

ASQ, Org (2018), on the other hand, states that according to the International Standard on Social responsibility (ISO 26000) organizational governance encapsulates a system by which an organization makes and implements decisions in pursuit of its set objectives. As such in the economic perspective, governance systems include the management processes designed to deliver on performance objectives while taking into account the interests of the stakeholders. Good governance is therefore somewhat involved with the management of facets and programs within an organization and not the organization itself to ensure ultimate efficiency of the characteristics 
that eventually contributes to the growth and development of the entire organization.

Despite churches considered to be not for profit making business and its lack of fit in the organizations with revenue and profit-making indulgences, it is an organization that receives an influx of money that among other duties, should contribute towards the growth and development of the essence of the church. This means, building and development of physical churches, participating in charity events, engaging highly in giving back to the society and most of all ensuring the availability of clergymen to help guide the population towards spiritual fulfilment. Robbins (2015) outlines that governance within organizations including non-business-related organizations like Churches is necessary elements which serve to establish and maintain order. As such to ensure the maintenance of order within churches as well as religious institutions and the proper utilization of resources, good governance is a necessary component.

In this study, an extensive literature review will be conducted in the areas of strategies adopted by Churches in increasing the number of its worshipers, spiritual growth, and Church activities to unearth the financial perspectives of Churches, as well as factors that impact the growth and development of Churches, (Nieuwhof, 2018; Patricia, 2016). Good governance regarding management of Church affairs also extends to the effective financial management such money collected through various conventional ways such as offerings and tithe which due to their lack of business value attachment cannot be audited or taxed by the state. The fact can never be disputed that effective corporate governance and management lead to the growth and development of profit-making businesses. Alternatively, insufficient research has been conducted in establishing the relationship between effective governance, management, and church structure in the growth and development of Churches.

As a result, investigating the relationship between good governance, management techniques and organizational structure for not-for-profit organizations such as Churches is therefore critical in assessing the impact of corporate governance, management and Church structure in the growth and development of Churches. The study will establish whether church governance systems can be utilized to manage spiritual activities as well as financial operations that will mutually contribute to the growth and development of Churches.

Searcy (2016) points out that among the potential and most often a barrier to the growth and development of a church is its leadership structures and the accountability of financial accounts as well as various activities conducted. The study, therefore, further appraise the potential of good governance as a technique to solve the problem of management in Churches by offering a systematic review of literature that builds upon the answering of questions border lining the three areas of research in the subject.

These questions include: What are some of the elements of good governance, management and Church Structure? What is the impact of good governance, management and Church Structure on the growth and development of Churches? What is the relationship between the governance and management of organizations?

\section{Method}

The study will employ a systematic review of literature through the analysis of available content on the various study areas. As such the research design employed Content analysis which is especially advantageous in this type of research study since it does not simulate experiences and opinions; instead, it engages in the analysis of the central aspect of a phenomenon directly in developing hypothesis and model. An extensive questionnaire with 60 open-ended questions will be developed base on the literature review to test the internal reliability and validity of the framework and its hypothesis of the study. The questionnaire will also include questions relating to the demographics of respondents and profile of their Church. All items will be measured on a Seven-Point-Likert scale ranging from strongly disagree to strongly agree ( $1=$ strongly disagree; $7=$ strongly agree).

The questionnaire will then be given to 30 Church pastors and senior ministers to ensure accuracy and consistency. Base on their feedback all corrections, suggestions and recommendations will be made accordingly. Respondents of this study will be contacted through telephone, email, and face to face at their church location prior to the study. The questionnaires will now be distributed to senior Church pastors and senior ministers in different Churches in the Greater Accra region of Ghana. Church pastors and senior ministers will be selected for this study since they play key roles in the decision-making process and serve as a representative of their Church, they are directly or indirectly responsible for the growth and development of the Church.

The above mentioned will be carried out by initially obtaining a list of all registered Churches under the Ghana Christian Council. For the purpose of this study, the only participant registered under the Ghana Christian Council will participate in this study. A randomly 250 selected churches will participate in this study. The randomization will be conducted using Excel 2013 randomize number generator to reduce selection bias and improve on the internal and external validity of the research. Respondents would be given options to fill out the 
questionnaire at their Church premises on a printed copy or through the use of online survey tools such as survey monkey, remotely.

Statistical Package for Social Sciences (SPSS) version 20 will be employed in analyzing descriptive statistics such as mean, standard deviation and frequency distribution, multiple regression and Exploratory Factor Analysis (EFA). Also, Analysis of Moment Structure (AMOS) version 24, will be used for Confirmatory Factor Analysis (CFA). Furthermore, (Cronbach's alpha) will also be conducted to test the reliability of each of the scales to assess internal consistency.

\section{Literature Review}

\subsection{Governance}

According to Gisselquist (2013) the term governance is utilized in great complexity depending on the context with which it is being used, however, for a governance to be excellent and productive, it must take into account respect for the rights of all individuals as well as adherence to the rule of law which offers the framework for conducting different activities. While good leadership systems do not necessarily guarantee good governance, the judgment and contents of good governance largely depends on the aim with which it is used: whereas in the financial context, good governance focuses more on economic reforms, in a more politicized and social organizations such as churches, focus is more on the human rights law (Johnston, 2017).

\subsection{Elements of Good Governance}

These two interpretations of governance set forth different elements of good governance that guarantee the achievement of growth and development on whichever organization they are implemented. In the economic perspective of good governance, Capacity, effectiveness and efficiency prime as the significant elements while in socio-political perspective the major elements include: human rights, democracy as well as responsiveness and accountability (Johnston, 2017). When it comes to the governance and management of the church's affair and ensuring the growth and development of both the spiritual and physical aspect of the church, it calls for a combination of these two approaches. It is an ideal form of governance, and the association between such dualistic approaches would impact significantly on the concept of governance and management of the church (Sarah, 2017).

\subsection{Economic Approach}

The economic approach of governance involves the use of governing structures and bodies to ensure sustainable use of available resources within organizations to most effectively and efficiently meet the needs of the organization (Creative Learning, 2018). It is about ensuring the organization can sustainably manage its operations in the present as well as in the future. Given the extensive sources of funds for churches as highlighted by (Rainer, 2018) include; partnerships with other churches, raising support such as, through fundraisers as well as the greater giving by a congregation through offerings and tithes. Good governance is crucial in ensuring accountability of the funds as well as their effective and efficient use in being able to contribute towards the physical enhancement of the church itself and indulging in other activities that impact the growth of the church. Eventually, despite the fact of whether the leaders are good or bad, a good governance structure impacts a proper management technique which is guaranteed to yield results.

\subsection{Socio-Political Perspective}

The socio-political perspective of governance is more interested in governance in the context of how an organizations management should act towards its members. Good governance according to this approach as highlighted by Rost (2017) should majorly be defined by human rights standards and only employee economic and managerial criteria as a secondary consideration. This is key especially within the church as the congregation represent the essence and significant component of the church, as such the governance system should be as critical in ensuring the upholding of the rights of the congregation, democracy as well as ensuring accountability for whatever the activity the church is involved. This ensures the congregation is spiritually nourished and satisfied and impacts on the church's continued growth and development.

\subsection{Managerial Practices}

For the past decades, there have several management ideas and concepts that have been developed in the quest for improving the efficiency and effectiveness to support the growth of businesses, Sutherland and Canwell, (2004). Daft, (2000) pointed out that most managers in the contemporary business world now employ effective management tools and processes in conducting their business practices.

In a practical sense, management of the church requires the same skill-set as that of any other business entity since 
they both share similar to the same characteristics. The fact can never be disputed that effective management is the backbone for organizational growth and development, especially among churches. Such managerial practice includes, planning and decision making, knowledge management, management by objectives, training and rewarding of staff, risk management, financial management, performance measurement, hospitality management, effective communication, technology/software management, facility management, managing of welfare committee, harvest committee, education committee and the various associations within the church.

As most churches are involved in the above-mentioned activities that can impact the growth and development of the church, there is the need for the adoption and implementation of effective managerial practices, such as efficacious planning and objectives that will involve laying down a viable functional schedule for a given period of time in the eventual realization of the church needs. Planning as a management function is tied to governance and leadership as all these activities are taken up by the stewards and individuals in the position of leadership within the church (Lundholm-Eades, 2005).

For effectual planning and execution, which enhances the management practices of a church structure and set up, pre-analysis of all the risks involved in the execution of various church functions as well as the management of time, finance and other resources is key for eventual success. Patricia (2016) listed among eight key factors to effective church management techniques to include: developing a strategy and budgeting process for the strategy, managing performance as well as looking out for any risks that may impede development and growth regardless of where the risk is expected to come from. Lipman (2013) emphasizes numerous management practices that are critical to the performance and success of an organization regardless of its nature to include: Planning, Performance management, Resource management and Risk management.

\subsection{The Relationship between Good Governance and Church Management}

One of the most critical factors of governance lies in its contribution to both prosperity and accountability of an organization (Uche and Atkins, 2015). In an organization such as a church, both elements are crucial for continued growth and development. However, how can the governance of a church ensure its adequate management and impact on its growth? Good Governance provides a framework for accountability to stakeholders, members and the leaders of an organization as well as to the broader society within which the organization is part of, Management. On the other hand, it is concerned with the day to day operations of the institutions in the milieu of the policies, procedures, and systems that have been established by the governing body. Governance is, therefore, the process by which management is controlled and checked by the stakeholders of the organization to ensure they are in line with the achievement of the objectives of the organization.

Having less responsible leaders as well as corrupt officials without a proper governing system might lead to the risk of embezzlement and thefts. In contrast, however, being able to have structures of governance in place can significantly minimize this through ensuring accountability. Uche and Atkins (2015) point out that an element of stewardship is expected from individuals selected for the management of such organizations by the stakeholders for which in this context are the congregation. From the stewardship theory of governance, stewardship means the assumption of a position to take care, fulfil, and protect the interest and needs of another person. Good governance systems within the church can, therefore, enable good leaders within the management of the churches and through effective stewardship stir the church through to growth and development.

These views are also supported by Misangyi and Acharya, (2014) who insists that stakeholders, who may be the investors, the customers, the public, the regulators, or the employees, in the context of this study, the congregation, commit to a relationship with the organization in which they communicate their interests and empower the bodies to pursue the said interests on their behalf. Stewardship governance, therefore, obliges those in management and governance positions within an organization to abandon their gains such as huge salaries and to be trustworthy and ensure they diligently serve the organizations to impact growth.

The agency theory can also be utilized to explain the connection and relationship between governance and management especially within an organization set up. According to Aguilera, Judge and Terjesen (2016), the theory assumes that the agent when representing the principal must do so in the best interest of the principal and it is the principal's responsibility to make sure of the agent's efficiency towards the management of their interests. The congregation, clergy, the community and other parties represent the principals in this context who stand to benefit from an improved and effectively developed church and are responsible for the development of a governance system to keep the church leaders in check who make up the agents managing the church activities and indulgences. 


\subsection{Church Structure}

\subsubsection{Episcopal Church Structure}

One of the earliest forms of church governance mainly consists of clergymen and bishops and the management committee of the church. Gillis (2018) points out that Episcopal borrows from a Greek term in the New Testament that describes an overseer, guardian or bishop highlighting that the governance structures main objective is to provide a framework for the overseeing of church activities and ensuring eventual significance in every action taken towards the achievement of the church's objectives. This type of governance focuses on a structure of priesthood in a specific local congregation or parish with the local congregation being governed or overseen by bishops.

\subsubsection{Presbyterian Church Structure}

The Presbyterian Church structure also referred to as the Presbyterian polity is a unique governance structure which intends to provide an equilibrium between the denomination and the congregation. Willour (2016) highlights that; the unique quality of the Presbyterian polity is that authority flows both from the congregation up and from the denomination down. In this sense, both the agent and the principal can ensure efficiency in governance and therefore impact on the ultimate church growth. The congregation ellects the leaders in the denomination in order to prevent the emergence and development of dominant hierarchies governed by one person which are toxic to the growth and development of the church. Once elected, leadership can exercise their authority over congregations. Regional groups of the congregation are a presbytery, and when they come together to form groups, they remain governed by a synod. The local congregations govern themselves through an elected board called a session (Willour, 2016).

\subsubsection{Congregational Church Structure}

This structure involves a senior pastor or staff or board that is responsible for and accountable for the congregation; numerous substructures exist within these structures that are variant in their composition based on one church to another. A notable fact is that the structure emulates the New Testament idea of the priesthood of every believer (Willour 2016). They include individual leaders that are accountable for entire congregations and therefore carry out the planning as well as management of church activities on their own accord.

3.7.4 Research Framework

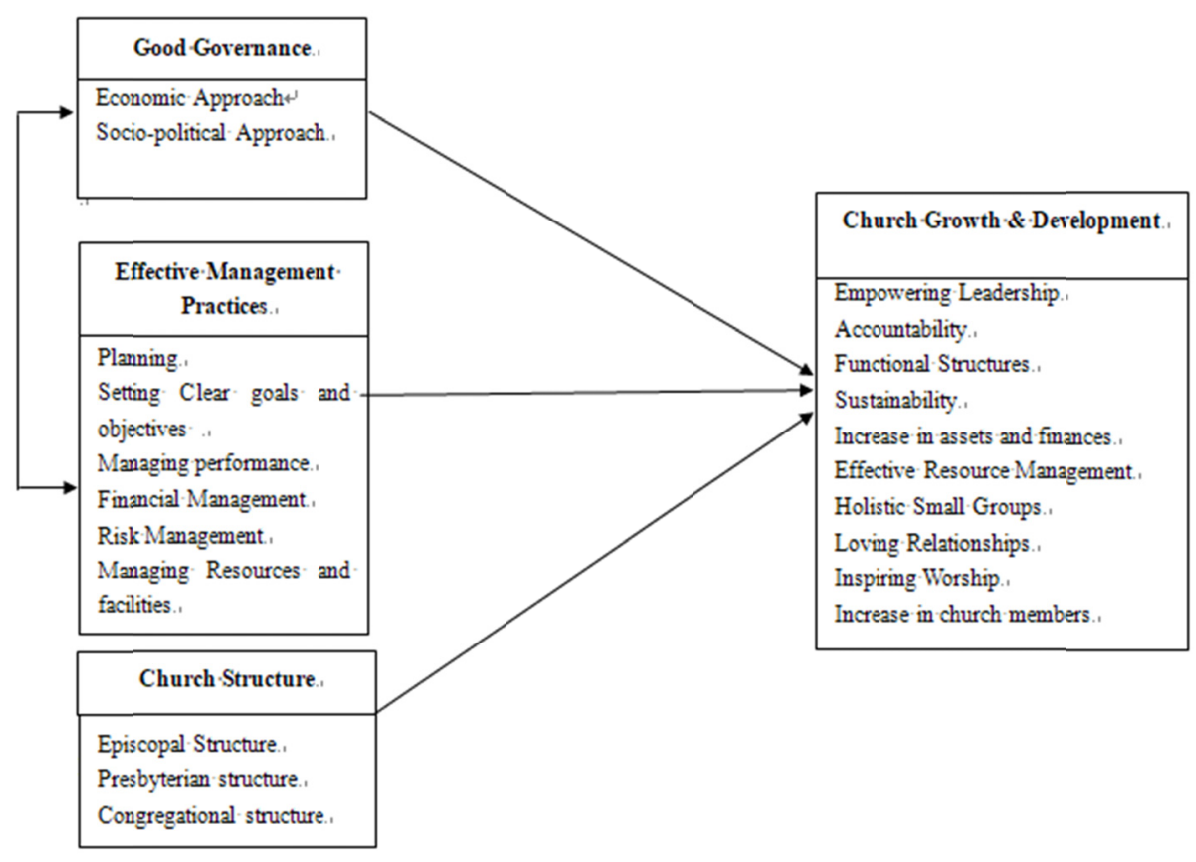

The findings of this study indicate that churches are social gatherings aimed at improving the society through the imparting and nurturing of a sense of belief to the congregation who in turn devote themselves to the various services of the church to ensure its growth and development. Regardless of the church receiving large amounts 
of funding every week from various sources, it is not legally obligated to disclose this amount to the congregation or any other individuals, and it is equally not tied by complex legal procedures such as payment of taxes. These funds are accrued through fundraising; proceeds from any business affiliated to the church; and contributions of the congregation through offerings and tithe. As such, to be able to account for the usage of the funds and resources adequately, the church's management should be highly efficient and dependable in conducting the related activities of the church and ensuring the sustainability of the church, in the present as well as in the future. While these management techniques and methods exist within almost all churches, (Robbins, 2018) disclosed that as a church begins to grow, its management capitalizes in cutting down the growth so as to stay in control of the logistics related to the growth, for instance, increased numbers of members of the congregation as well as planning of increased number of services.

H1: The study, therefore, reveals that there is a relationship between good governance and the growth and development of churches.

Effective management of the church functions and interest, such as religious activities, developing a remuneration and allowance policy for the clergy who provide the services of facilitating spiritual nourishment, facility maintenance, community development, church construction works, and budgeting for other church activities. These, therefore, calls for a multitude of activities which must be unequivocally taken up by stewards and individuals in managerial positions within the church to ensure the growth and development of the church, in areas such as spiritual growth, increase in members, empowering leadership, resource management, loving relationships, and holistic small groups. With a good management system, the church is capable of effective growth and development regardless of the type of leadership or governance it has since effective management.

$\mathrm{H} 2$ : The study, therefore, hypothesis that there is a relationship between management on the growth and development of churches.

The church represents one of the components of society given that the concept of religion has been part of human life since as long as humans themselves have existed. For the Church to ensure sustained spiritual nourishment and growth of individual congregations as such, it must develop viable plans and objectives that are reflective to their visions, missions as well as beliefs to be able to attract a congregation and spread the gospel as intended. They must be able to sell this idea to the congregation alongside religious services and messages to get the congregation to contribute towards the growth and development of the church.

Nevertheless, given the availability of a variety of ways that a church can gain funds, there is an imperative need for governance and management structures that will not only be responsible for ensuring the running of the church but also ensure its further growth and development as well as its sustainability in the present and the future. While there are no prescribed methodologies or structures for church governance three known structures including the Episcopal, the Presbyterian and the congregational structures exist to enable churches to be able to manage their church activities processes in a stable and viable way to ensure sustainable growth and development.

While two of these structures, the Episcopal and The Presbyterian governance structures are quite specific in their composition and their flow of power and authority, the congregational governance structure is more open to customization based on the church and the leadership of the church in line to the set visions, missions and objectives.

Eventually, governance structures within churches and especially when managed well has the capacity of impacting the church's management functions and ensuring the efficient and effective utilization of resources that enable the realization of growth and development within various avenues of the church.

H3: The study, therefore, hypothesis that there is a relationship between church structure on the growth and development of churches.

\section{Discussion}

Given the establishment of churches solely as places of worship and delivery of spiritual guidance and nourishment, the governance and management structures are typically developed within the context of the specific church and rely on laws enforced within these same contexts. The compositions of governance and management, therefore, vary widely from one church to another all across the globe. However, according to Pfang (2013), most churches are organized as organizations which legally obliges them to have a board of directors to govern the matters related to the church. Among the other functions of this board include overseeing the operations of the ministry and management of the church's resources to ensure their sustainable, effective and efficient usage. This may include ministry budgeting, capital expenditures, legal compliances and risk 
management within the church operations.

The management of a church equally requires clear set strategies that are measurable, and appraisable to determine the efficiency and effectiveness towards its growth. Patricia (2016) highlight among the essential requirements for effective management of a church to include developing a growth and development plan and strategy which entails setting goals, engaging in productive budgeting processes, managing performance, managing facilities and legal as well as risk management. The church like any other organization must properly conduct its activities to ensure accountability and therefore sustainability that is guaranteed to translate to performance and growth.

The structured planning and strategies developed with the consideration of the church's vision, mission and values as such the individuals within the management of the church must subscribe to the church's mission, vision and values to have a clear means of how to execute the mandate (Pfang, 2013). According to (Robbins, 2018) church structure and leadership is an essential part of ensuring its continued growth. In most churches, as the church grows, the organization of the church begins to hinder its growth in an attempt to remain in control and avoid being overwhelmed. This is due to the dynamics of church growth including the need for accommodation of more people, stretching the budget to accommodate a growing congregation, an increased amount of problems that need solving with the increasing number of people, scheduling and funding more events and many others. To control this and remain in control the church can suppress growth through its governance and leadership structures.

In addition to the above-mentioned, the church as an organization is made up of numerous departments including the adults, the youth as well as the kids all of who have concurrent plans of growth and development that must be kept in check to ensure their viability and sustainability in terms of the ultimate church plans and objectives (Sarah, 2017).

\section{References}

Aguilera, R. V., Judge, W. Q., \& Terjesen, S. A. (2018). Corporate governance deviance. Academy of Management Review, 43(1), 87-109. https://doi.org/10.5465/amr.2014.0394

ASQ. Org. (2018). What is Corporate Governance? Organizational Governance Defined|ASQ. Retrieved from https://asq.org/quality-resources/governance

Creative Learning. (2018). What is Good Governance?-Creative Learning. Retrieved from http://creativelearning.org/blog/2016/11/08/what-is-good-governance/

Daft, R. L. (2000). Management. Fort Worth, TX: The Dryden Press.

Gillis, J. (2018). Toward an Understanding of Church Governance - Jerry Gillis. Retrieved from http://jerrygillis.com/blog/church-governance/

Gisselquist, R. M. (2013). Good Governance as a Concept, \& Why This Matters for Development Policy. United Nations University, Working Paper.

Johnston, M. (2017). Political corruption: Concepts and contexts. Routledge. https://doi.org/10.4324/9781351308366

Lipman, V. (2013). 7 Management Practices That Can Improve Employee Productivity. Retrieved from https://www.forbes.com/sites/victorlipman/2013/06/17/7-management-practices-that-can-improve-employe e-productivity/\#20fc065b484c

Lundholm-Eades, J. (2013). Best Practices in Church Management. Retrieved from https://www.americamagazine.org/issue/554/article/best-practices-church-management

Misangyi, V. F., \& Acharya, A. G. (2014). Substitutes or complements? A Configurational examination of corporate governance mechanisms. Academy of Management Journal, 57(6), 1681-1705. https://doi.org/10.5465/amj.2012.0728

Nieuwhof, C. (2018). Seven Things That Will Drive Future Church Growth - Carey Nieuwhof.com. Retrieved from https://careynieuwhof.com/7-things-will-drive-future-church-growth/

Patricia. (2016). 8 Keys to Effective Church Management - Smart Church Management. Retrieved from https://smartchurchmanagement.com/effective-church-management/

Patricia. (2018). Seven Keys to Church Growth-Smart Church Management. Retrieved fromhttps://smartchurchmanagement.com/keys-to-church-growth/ 
Pfang, R. (2014). Management in the Catholic Church: corporate governance. Journal of Management, Spirituality \& Religion, 12(1), 38-58. https://doi.org/10.1080/14766086.2014.933708

Rainer, T. (2018). Five Sources of Funding for Church Revitalizing and Replanting. Retrieved from https://thomrainer.com/2018/07/five-sources-funding-church-revitalizing-replanting-revitalize-replant-050/

Robbins, D. (2018). What is church government, \& why is it necessary? Retrieved from http://www.victorious.org/cbook/chur44-church-government

Rost, K. (2017). Introduction to the Corporate Governance of Religion. In Scott, Robert A; Buchmann, M. (Eds.), Emerging Trends in the Social and Behavioral Sciences: An Interdisciplinary, Searchable, and Linkable Resource. Hoboken: Wiley-VCH, 1-10. https://doi.org/10.1002/9781118900772

Sarah, R. (2017). The benefits of good corporate governance to small and medium enterprises (SMEs) In South Africa: A view on top 20 and bottom 20 JSE listed companies. Problems and Perspectives in Management, 15(4), 271-279. https://doi.org/10.21511/ppm.15(4-1).2017.11

Searcy, N. (2016). 5 Barriers to Church Growth. Retrieved from https://churchleaders.com/pastors/pastor-articles/145785-nelson-searcy-barriers-to-church-growth.html

Sutherland, J., \& Canwell, D. (2004). Key concepts in management. New York: Palgrave MacMillan.

Uche, C. O., \& Atkins, J. F. (2015). Accounting for rituals and ritualization: The case of shareholders' associations. In Accounting Forum (Vol. 39, No. 1, pp 34-50). Elsevier. https://doi.org/10.1016/j.accfor.2014.10.006

Willour, G. (2016). Lake Presbyterian Church the Advantages of Presbyterian Church Government. Retrieved from http://lakeopc.net/2016/the-advantages-of-presbyterian-church-government/

Worldbank.Org. (2018). Retrieved from http://siteresources.worldbank.org/EXTGLOREGPARPROG/Resources/grpp_sourcebook_chap12.pdf

\section{Copyrights}

Copyright for this article is retained by the author(s), with first publication rights granted to the journal.

This is an open-access article distributed under the terms and conditions of the Creative Commons Attribution license (http://creativecommons.org/licenses/by/4.0/). 